locturos which over the years has been modified and polishod until the author foels it represents the perfect approach to his subject. These methods help to ensure comploteness and accuracy, but too often fail to produce a readable book. In this book Clinton Brown and George Webb have followed a different course. Dr. Brown is clearly a man with wido and extensive knowledge of his subject-both biologically and electronically - as well as a rare gift for putting across his ideas. It would almost be worth having this book for the first chapter alone, for there can be few biologists who would not find something of value in this discourse on the use-and misuse- of instrumontation in biology to-day and in the foreseeable future. The whole chapter is erninently quotable, but one short passage must suffice: "Roduced power, space and weight are obvious advantages of the transistorized instrument but their greatest irnportance has boen in the invention of new devices. The descondants of the transistor; the four layer diode, somiconductor strain element, photosensitive device, controlled rectifier, Esaki diode are such radical departures from tho original transistor as to rosemblo now species. Commercial applications are available to-day for functions formerly considered impossible or impructical". The quotation is significant: ono suspocts that Mr. Webb (the electronic collaborator) made it a point of honour to soo that no new deviee of bioelectronic value was omitted, and as the book proceeds tho distinctions between, for example, different types of four layor diodes is clearly explained with ample indication of typical circuit configurations.

One inevitable flaw in a book which has virtually been written by one man-and almost certainly over a short poriod - is that a number of inaccuracies and inconsistencics have slipped in. Misprints such as (p. 43) $X_{L}=2$ pifL are not misleading, but on this side of the Atluntic some readers may be caught out by the statement that the current in a hundred-watt lamp is about one amp (p. 35). (No voltage is stated.) More misleading is the implication that capacitors in series are additive (Colpitts oscillator, p. 157), while the statement that transformer coupling is unsatisfactory "at the low power and low frequencies encountered" (p. 121) surely requires further comment since no indication is given that two quite separate problems are involved. Again in one or two places the legends on the diagrams do not agree with the text, but in one place (p. 75) both diagram and text are wrong: "In (Fig. 5: 14B) the signal increases smoothly from zero to some value where it drops to zero. The differential of this signal is a square wavo".

It is difficult to comment on some numorical data without knowing which devices the author has in mind, but he describes a CdS cell illuminated at $400 \mathrm{c} / \mathrm{s}$ by a neon lamp (p. 140) as a form of choppor for a d.c. amplifier. I fool that this could be misleading as, while high-speed CdSe cells are availablo, the vast majority of photosensitive resistors would not follow this frequency satisfactorily. On the other hand, to say (p. 102) that the reverse current in a diode is "less than 5 per cent" seems very cautious, even by germanium standards. A typical silicon loakago figure would be 0.1 amp for a diode with a maximum forward current of $100 \mathrm{~m}$.amp (Mullard $O A$ 200) while a forward/reverse ratio of a thousand is now common oven. among germanium devices.

Although, rather surprisingly, abbreviations $\Omega, K \Omega$, $\mathrm{M} \Omega, \mathrm{A}, \mathrm{mA}, \mu \mathrm{A}, \mathrm{nA}$, otc., are not explained, their omission is the more conspicuous since the development of symbolism and ideas is elsewhere excellent: the chapter on. signal conditioning systems and on digital logic being particularly good.

To sum up: this book is well written, amply and skilfully illustrated and, despite numerous minor lapses, should be of great valuo both to bioongineers and to biologists. It does not describe any complete apparatus - that is not its object-but it does describe clearly and in simple terms the working of virtually every semi- conductor device available to-day and discusses ways in which apparatus built around such devices can be profit. ably used in a biological laboratory.

J. R. B. Greier

\section{SOVIET CHEMISTRY}

\section{Chemistry in the Soviet Union}

By Prof. John Turkovich. Pp. ix +566 . (Princeton, N.J.: D. Van Nostrand Company, Ine.; London: D. Van Nostrand Company, Ltd., 1965.) $93 s$.

$\Lambda^{\mathrm{T}}$ a meeting of the Russian Chemical Society on A March 6, 1869, tho periodie law was first presonted to the world by Menshutkin, acting for Mendeleev, who was ill. Mendeleev later became the 'best-known Russian chemist'. In conformity with Prof. Turkevich's trentmont of othor topics, he should havo mentioned Newlands of London, who in all essential detail presented the same concept in 1864; and these few years were eritical in the matter of atomic weights. Ignored is the letter in Chemical News of 1882 (p. 278) in which Newlands remarks on the reception of the Davy Medal by Mendeleev "for his discovery of the periodic relation", and draws attention to his own publications of 1864 and 1865. Ignored, too, is the letter by Mendeleev himself in Chemical News of 1881 (p. 15), in which he admits "it is possible that Newlands has prior to me enunciated something similar to the periodic law".

Those of us brought up in the classical days will recall the full-sounding names of Lomonosov (1711-1765), Tschitschibaban and Zelinski. Klaus contributed to the knowledge of the chomistry of osmium and iridium, and in 1844 discovered ruthenium, named after the Latin name for Russia. P. Walden worked mainly on non-aqueous electrolytic solutions; but is best known for his isolated discovery of the optical inversion.

This book is mainly about Russian chemists and educational (research) institutos. The history of chemistry in Russia from the fifteenth to the middle of the ninetcenth centuries is outlined in six pages, and, in 12 pages, prominent chemists in the second half of the nineteenth century are mentioned. We read that Butlerov (18261886 ) is given credit by Western authorities for introducing the expression 'structure' into organic chemistry; but the Soviet chemists now claim a greater role for him as the one who formulated the structural theory of organic chemistry. "Tho solution of this problem could only be the lot of a scientist that is not only of outstanding talent but also free from the enumerated (p. 36) shorteomings which were inherent in the majority of important Western European chemists." "The honour of ercating a now theory which exerted a revolutionary influence on further dovolopment of organic chemistry, fell to a Russian chemist, A. M. Butlerov." "Tho standard text-books in the West do not mention his eminence in this role." Markovnikov (1838-1904), a student of Butlerov, was a leader of the Russian scientific circles of his poriod.

In the next 29 pages, chemistry in Russia in the ninetoenth and twentieth centuries is summarized under the usual headings, such as organic, colloid, analytical chemistry; and similar summaries on Soviet chemistry betweon the two World. Wars are given in 91 pages.

For those who have maturity and time for quiet, thoughtful reading at home, these 140 pages can provide intonsivo pleasure, and a grasp of the activities of Russian chemists not otherwise so readily achicved. Thore are 30 helpful pages on the activities of chemical research estab. lishments in the U.S.S.R., but the remaining 393 pages could well have been relegated to a library handbook; for these show a list of names of authors, and the titles of dissertations in chemistry at the Soviet universities, as well as a similar list of recent publications of members of the U.S.S.R. Academy of Sciences.

W. (MERRARD 